\title{
Correction to: Efficient Hardware Architectures for 1D- and MD-LSTM Networks
}

\author{
Vladimir Rybalkin ${ }^{1}\left(\mathbb{D} \cdot\right.$ Chirag Sudarshan $^{1} \cdot$ Christian Weis $^{1} \cdot$ Jan Lappas $^{1} \cdot$ Norbert Wehn $^{1} \cdot$ Li Cheng $^{2}$
}

Accepted: 10 July 2021 / Published online: 22 November 2021

(c) The Author(s) 2021

\section{Correction to: Journal of Signal Processing Systems (2020) 92:1219-1245 https://doi.org/10.1007/s11265-020-01554-x}

The article "Efficient Hardware Architectures for 1D- and MD-LSTM Networks", written by Vladimir Rybalkin, Chirag Sudarshan, Christian Weis, Jan Lappas, Norbert Wehn, Li Cheng, was originally published Online First without Open Access. After publication in volume 92, issue 11, page 1219-1245 the author decided to opt for Open Choice and to make the article an Open Access publication. Therefore, the copyright of the article has been changed to CThe Author(s) 2020 and the article is forthwith distributed under the terms of the Creative Commons Attribution 4.0 International License, which permits use, sharing, adaptation, distribution and reproduction in any medium or format, as long as you give appropriate credit to the original author(s) and the source, provide a link to the Creative Commons licence, and indicate if changes were

The original article can be found online at https://doi.org/10.1007/ s11265-020-01554-x.

Vladimir Rybalkin

rybalkin@eit.uni-kl.de

Chirag Sudarshan

sudarshan@eit.uni-kl.de

Christian Weis

weis@eit.uni-kl.de

Jan Lappas

lappas@eit.uni-kl.de

Norbert Wehn

wehn@eit.uni-kl.de

Li Cheng

licheng56@huawei.com

1 Technische Universität Kaiserslautern, Kaiserslautern, Germany

2 Huawei Technologies Co., Ltd., Chengdu, China made. The images or other third party material in this article are included in the article's Creative Commons license, unless indicated otherwise in a credit line to the material. If material is not included in the article's Creative Commons license and your intended use is not permitted by statutory regulation or exceeds the permitted use, you will need to obtain permission directly from the copyright holder. To view a copy of this license, visit http://creativecommons. org/licenses/by/4.0. Open access funding enabled and organized by Projekt DEAL.

The original article has been corrected.

Open Access This article is licensed under a Creative Commons Attribution 4.0 International License, which permits use, sharing, adaptation, distribution and reproduction in any medium or format, as long as you give appropriate credit to the original author(s) and the source, provide a link to the Creative Commons licence, and indicate if changes were made. The images or other third party material in this article are included in the article's Creative Commons licence, unless indicated otherwise in a credit line to the material. If material is not included in the article's Creative Commons licence and your intended use is not permitted by statutory regulation or exceeds the permitted use, you will need to obtain permission directly from the copyright holder. To view a copy of this licence, visit http://creativecommons.org/licenses/by/4.0/.

Publisher's Note Springer Nature remains neutral with regard to jurisdictional claims in published maps and institutional affiliations. 